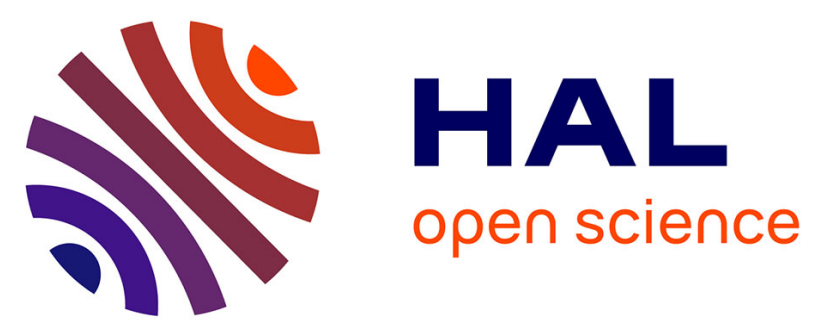

\title{
First detailed description of Hispanomys bijugatus Mein and Freudenthal, 1971 (Rodentia, Cricetodontinae) from the Upper Aragonian of La Grive-Saint Alban (France): Biostratigraphical implications
}

Raquel López-Antoñanzas, Pierre Mein

\section{To cite this version:}

Raquel López-Antoñanzas, Pierre Mein. First detailed description of Hispanomys bijugatus Mein and Freudenthal, 1971 (Rodentia, Cricetodontinae) from the Upper Aragonian of La GriveSaint Alban (France): Biostratigraphical implications. Geobios, 2009, 42 (6), pp.783 - 796. 10.1016/j.geobios.2009.04.002 . hal-01920967

\section{HAL Id: hal-01920967 https://hal.science/hal-01920967}

Submitted on 17 Dec 2020

HAL is a multi-disciplinary open access archive for the deposit and dissemination of scientific research documents, whether they are published or not. The documents may come from teaching and research institutions in France or abroad, or from public or private research centers.
L'archive ouverte pluridisciplinaire HAL, est destinée au dépôt et à la diffusion de documents scientifiques de niveau recherche, publiés ou non, émanant des établissements d'enseignement et de recherche français ou étrangers, des laboratoires publics ou privés. 
Elsevier Editorial System(tm) for Geobios

Manuscript Draft

Manuscript Number: GEOBIO-D-09-00006R1

Title: First detailed description of Hispanomys bijugatus Mein et Freudenthal, 1971 (Rodentia, Cricetodontinae) from the Upper Aragonian of La Grive-Saint Alban (France): biostratigraphical implications

Article Type: Original article / Article original

Keywords: Hispanomys; Cricetodontinae; Miocene; Systematics

Corresponding Author: Dr. Raquel López-Antoñanzas, Ph.D.

Corresponding Author's Institution: Museo Nacional de Ciencias Naturales-CSIC

First Author: Raquel López-Antoñanzas, Ph.D.

Order of Authors: Raquel López-Antoñanzas, Ph.D.; Pierre Mein, Ph.D.

Abstract: The material of Hispanomys bijugatus (Rodentia, Cricetodontinae) from La Grive-Saint Alban (Carrière Lechartier, fissure L3) is described for the first time and compared with all species of the genus known to date. As common in the Upper Aragonian populations of Hispanomys, this taxon evidences a low variability. Hispanomys bijugatus shows some progressive characters with respect to the remaining Aragonian congeneric species, such as the absence of labial and lingual cingula surrounding the upper and lower molar valleys respectively, the increase in the number of roots on the second lower molar, and the lost of mesolophs. This suggests that $\mathrm{H}$. bijugatus, in spite of being one of the oldest species of the genus, is relatively derived with regard to the coeval congeneric species. Because $\mathrm{H}$. bijugatus and $\mathrm{H}$. decedens are believed to be closely related species within the same lineage, the fact that the former shows a more progressive dental morphology than the latter suggests that the unnamed fissure-filling from La Grive and La Grive M (with $\mathrm{H}$. decedens only) are older than La Grive L3 (with H. bijugatus only). The coexistence of both species at locality L5 suggests an intermediate age. 

First detailed description of Hispanomys bijugatus Mein et

Freudenthal, 1971 (Rodentia, Cricetodontinae) from the

Upper Aragonian of La Grive-Saint Alban (France):

biostratigraphical implications

Première description détaillée d'Hispanomys bijugatus Mein

et Freudenthal, 1971 (Rodentia, Cricetodontinae) de-de

l’Aragonien supérieur de La Grive-Saint Alban (France) :

implications biostratigraphiques

Raquel López-Antoñanzas ${ }^{1}$ and P. Mein ${ }^{2}$

${ }^{1}$ Departamento de Paleobiología, Museo Nacional de Ciencias Naturales-CSIC, c/ José Gutiérrez Abascal 2, Madrid 28006,Spain.E-mail: ralopan@mncn.csic.es

${ }^{2}$ Département des Sciences de la Terre; Université Claude Bernard-Lyon I; 27-43 Bd. du 11 novembre 1918; Villeurbanne 69622 cedex, France.E-mail: Pierre.Mein@univ-

lyon1.fr

\footnotetext{
Abstract

The material of Hispanomys bijugatus (Rodentia, CricetidaeCricetodontinae) from La Grive-Saint Alban (Carrière Lechartier, fissure L3) is described for the first time and compared with all species of the genus known to date. As common in the Upper
} 
Aragonian populations of Hispanomys, this taxon evidences a low variability.

Hispanomys bijugatus shows some progressive characters with respect to the remaining Aragonian congeneric species, such as the absence of labial and lingual cingula surrounding the upper and lower molar valleys respectively, the increase in the number of roots on the second lower molar, and the lost of mesolophs. This suggests that $H$. bijugatus, in spite of being one of the oldest species of the genus, is a relatively derived with regard to the coeval congeneric species. Because $H$. bijugatus and $H$. decedens are believed to be closely related species within the same lineage, the fact that the former shows a more progressive dental morphology than the latter suggests that the unnamed

Formatted: Font: $12 \mathrm{pt}$

Formatted: Font: $12 \mathrm{pt}$ fissure-filling from La Grive and La Grive $\mathrm{M}$ (with $H$. decedens only) are older than La

Formatted: Font: $12 \mathrm{pt}$ Grive L3 (with $H$. bijugatus only). The comparison of $H$. bijugatus with $H$. decedens (both recorded at various sites of La Grive-Saint Alban) suggests that the most recent localities may be those in which $H$. bijugatus is recorded (L5 and L3). The oldest ones may be $L 7$ and $M$, in which only the species $H$. decedens has been recovered. The coexistence of H. bijugatus and H. decedensboth species at locality L3-L5 suggests for this loeality an intermediate age between $\mathrm{L} 5$ on one side and $\mathrm{L} 7 \mathrm{and} \mathrm{M}$ on the other.

\section{Résumé}

Le matériel d'Hispanomys bijugatus (Rodentia, Cricetidae) de La Grive-Saint Alban

(Carrière Lechartier, fissure L3) est décrit pour la première fois et comparé avec toutes les autres espèces du genre connues actuellement. Comme il a déjà été observé chez d'autres populations d'Hispanomys de l'Aragonien superieur, ce taxon présente une faible variabilité. Hispanomys bijugatus montre des caractères dérivés par rapport au reste des espèces congénériques aragoniennes, tels que-: l'abscence de cingulums 
labiaux et linguaux sur les molaires supérieures et inférieures, respectivement ;

l'augmentation du nombre de racines de la deuxième molaire inférieure ; la perte des mésolophes. H. bijugatus, tout en étant une des plus anciennes espèces du genre, serait donc plus évolué que les espèces d'Hispanomys contemporaines. Etant donné qu' $H$. bijugatus et H. decedens sont considérées comme des espèces proches au sein de la

Formatted: French (France) $\underline{\text { même lignée, le fait que la première montre une morphologie dentaire plus dérivée que }}$ la seconde suggère La comparaison d'H. bijugatus avec H. decedens (tous deux présents dans plusieurs sites de La Grive-Saint Alban) suggère que les gisements les plus récents sont ceux dans lesquels H. bijugatus a été recueilli (L5 et L3). Les plus anciens seraient Lque la 7 fissure non nommée de La Grive et La Grive $\mathrm{M}_{-}$_où seul $H$. decedens a été collectée) sont plus anciens que La Grive L3 (avec H. bijugatus seul). La coexistence de H. bijugatus et H. decedensces espèces à La Grive L3-L5 suggère un âge intermédiaire entre celui de L5 d'un côté et celui de L7 et de M de l'autre.

Keywords: Hispanomys; Rodentia; CricetodontidaeCricetodontinae; Miocene; La Grive-

Saint Alban; France; Systematics

Mots clés: Hispanomys; Rodentia; Miocène; Cricetodontinae; La Grive-Saint Alban; France; Systématique

\section{Introduction}

La Grive-Saint-Alban is the common name used to refer to various pits located on the territory of the municipality of Saint-Alban-de-Roche. These pits are constituted by 
limestones whose fissures are filled by fossiliferous siderolitic clays. The name La Grive-Saint-Alban was given by Jourdan in 1861 in his first work dealing with the fauna of this area (specifically from the Peyre et Beau quarry). Jourdan was the first to carry out field works in the Peyre et Beau pit between 1845 and 1861. During the XIXth and XXth centuries, other pits such as the Milliat or the Lechartier ones were excavated. The pits were named after their owners and, therefore, they could be re-baptized when the owner changed. Nowadays, they are known with the following names: "Chemin départemental 24” (CD24), “carrière Lechartier" (L), “carrière Milliat" (M), “carrière Peyre et Beau" (P. B.), and "carrière nouvelle" (F), which is the most recently discovered one (Fig. 1). One of us ( $\underline{\text { Since } 1962 \text { one of us (P. M.) has been interested in }}$ La Grive-Saint-Alban. He excavated at the found the first micromammal in La GriveSaint-Alban (Lechartier and Milliat pits), and also found some micromammal remains at the Peyre et Beau pit. P. M. was the first person to latter evidencede that the different fissure fillings are asynchronous (Mein, 1976).

All pits_, but P.B., have yielded micromammals, but remains of Hispanomys have only been enly-recovered in La Grive $\mathrm{L}_{2}$ and-M-and P.B. (where a unique $\mathrm{m} 1 \mathrm{has}$ been found by P. M) P.B. (where a sole $\mathrm{ml}$ was found by P. M.) as well as in an unnamed fissure-filling. L (pit Lechartier) have eight fissure-fillings numbered from L1 to L8, but the only productive ones (from a palaeontological viewpoint) are L3, L5, L6, and L7. H. bijugatus has been recorded from fissures L3 and L5, whereas $H$. decedens has been found from-in an unnamed fissure-filling as well as in fissures $\mathrm{L} 3, \mathrm{~L} 5 \underline{\mathrm{L} 5}, \mathrm{~L} 7$, as well as, and from-in La Grive M (Mein and Ginsburg, 2002). Interestingly enough, almost all material of $H$. decedens from La Grive comes from this unnamed fissureInterestling (comes quite all material of $H$. decedens of $\mathrm{La}$ Grive. Interestlying

Formatted: Not Highlight

Formatted: Highlight

Formatted: Justified, Indent: First line: 0.5 ", Tab stops: $2.95 "$, Centered 
We agree with Mein and Ginsburg (2002) who did not mention the presence of $H$. decedens in L7 because they considered that the low percentage of this taxon in the sample was possibly the result of "contamination". The species Hispanomys bijugatus was originally erected as Cricetodon (Hispanomys) bijugatus by Mein and Freudenthal (1971), on the basis of isolated cheek teeth recorded from the locality L3 of La GriveSaint Alban (Mein and Ginsburg, 2002). As Mein and Freudenthal's (1971) work dealt with a whole revision and a new classification of the European tertiary cricetid record, a complete description of the wealth of material of Cricetodon (Hispanomys) bijugatus available could not be supplied and only a brief diagnosis was provided. Additional material of this taxon has been recovered at locality L5 (Mein and Freudenthal, 1971, Mein and Ginsburg, 2002; Maridet, 2002) as well as at the localities of-Lo Fournas 5, Pyrénées-Orientales, France (Aguilar et al., 1999) and Jujurieux, Ain, France (Mein, 1999), which are both MN9 localities (Montuire et al., 2006; Mein, 1999).

The aim of the present work is to offer a detailed description of Hispanomys bijugatus as well as comparisons with all the other species of the genus known to date. The degree of evolution of the teeth of the two species of Hispanomys recovered at La Grive is used to elucidate the relative infill chronology of the different localities, which is controversial.

\section{Material and methods}

The systematic study presented below is based on the examination of original specimens of the MNCN, RUU, IPS, and FSL collections (see below), and data from the literature. We examined the following: original teeth of Hispanomys bijugatus and 
H. decedens from La Grive Saint-Alban (Isère, France), H. mediterraneus from the localities of Montredon (Hérault, France), Soblay (Ain, France), and Dionay (Isère), $H$. aguirrei from Escobosa (Soria, Spain), H. daamsi from Can Missert (Barcelona, Spain), H. dispectus from Hostalets de Pierola and Castell de Barbera (Barcelona), H. lavocati from Hostalets de Pierola(Barcelona), H. aragonensis from Pedregueras 2A (Saragossa, Spain), H. nombrevillae from Molina de Aragón (Guadalajara, Spain), H. peralensis from Peralejos 4, Peralejos C, Peralejos D, Masía del Barbo 2A and Masía del Barbo 2B (Teruel, Spain), H. thaleri from Can Llobateres (Barcelona), H. freudenthali from Puente Minero (Teruel), and H. adroveri from Casa del Acero (Murcia, Spain).

The material of Hispanomys bijugatus from the iserois sites of La Grive-Saint Alban (Carrière Lechartier, fissure L3 and L5) is described for the first time and compared with the equivalent teeth of all the species of Hispanomys known to date. The occlusal measurements (maximum length and maximum width) were taken following Van de Weerd (1976) for all dental elements but upper second molars were the maximum length has been taken parallel to the labial side of the tooth. Measurements have been obtained using a Microscope Leitz Ortholux with a platinum ultrapack (Tab. 1, Fig. 2).

First, second, and third lower molars are designed as $\mathrm{m} 1, \mathrm{~m} 2$, and $\mathrm{m} 3$ respectively $_{2}$ Formatted: Indent: First line: 0.25 " whereas first, second, and third upper molars as M1, M2, and M3. The terminology used in the tooth descriptions follows that of Freudenthal et al. (1994). We use the local subzones of Van Dam et al. (2001) when relevant.

Institutional Abbreviations: FSL, Université Claude Bernard, Villeurbanne, France; IPS, Instituto Catalán de Paleontología, Sabadell, Spain; MGISTL, Museu Geológico, Lisboa, Portugal; MNCN, Museo Nacional de Ciencias Naturales, Madrid, 
Spain; MSNL, Centre de Conservation et d'Etude des Collections, Lyon, France; RGM, Nationaal Natuurhistorisch Museum Leiden, The Netherlands; RUU, Rijksuniversiteit Utrecht, Utrecht, The Netherlands; USTL, Université des Sciences et Techniques du Languedoc, Montpellier, France.

\section{Systematic paleontology}

ORDER RODENTIA Bowdich, 1821

FAMILY CRICETODONTIDAE Schaub, 1925

SubFAmily CRICETODONTINAE (Stehlin \& Schaub, 1951)

GENUS Hispanomys Mein et Freudenthal, 1971

SPECIES Hispanomys bijugatus Mein et Freudenthal, 1971

(Figs. 3, 4)

Holotype: FSL n ${ }^{\circ}$ 65478: left isolated $\mathrm{m} 1$ (Mein and Freudenthal, 1971, p. 37, Pl. 2, Fig. 4)

Paratypes: FSL 66256-66524

Type locality: La Grive-Saint Alban (Carrière Lechartier, fissure L3) Age: $\mathrm{MN} 8$

Other localities: La Grive-Saint Alban (Carrière Lechartier, fissure L5-and L7), Isère, France (Mein and Freudenthal, 1971); Lo Fournas 5, Pyrénées-orientales, France (Aguilar et al., 1999); Jujurieux, Ain, France (Mein, 1999)

Extended diagnosis: Hispanomys species of medium size, with weak or absent grooved upper incisors and low hypsodonty; having low values of the mean LM1/mean 
LM3 and mean Lm1/mean Lm3 ratios (unreduced third lower and upper molars not reduced); lower molars lacking cingula on the lingual valleys and having well_

developed labial anterolophid; $\mathrm{m} 1$ having a double metalophid and lacking mesolophid, $\mathrm{m} 2$ and $\mathrm{m} 3$ with short, but distinct, mesolophid; three rooted $\mathrm{m} 2$; upper molars lacking mesoloph, enamel coated valley, and labial cingula, and having incomplete lingual cingula and partial anterior ectoloph; M1 with four roots, with spur of the anterolophule and prominent protostyle; upper molars with vestigial entomesoloph.

Differential diagnosis: Differing from Hispanomys daamsi, $H$. thaleri, $H$. freudenthali, and $H$. adroveri, in being smaller; differing from $H$. castelnovi, $H$. aguirrei, $H$. daamsi, $H$. dispectus, $H$. thaleri, $H$. lavocati, $H$. nombrevillae, $H$. aragonensis, $H$. peralensis, $H$. baixasi, $H$. freudenthali, and $H$. adroveri in having an entomesoloph on some upper molars; differing from $H$. castelnovi, $H$. decedens, $H$. aguirrei, $H$. daamsi, $H$. dispectus, $H$. lavocati, $H$. nombrevillae, and $H$. aragonensis in lacking labial cingula surrounding the valleys on the upper molars; differing from $H$. mediterraneus, $H$. peralensis, $H$. freudenthali, and $H$. adroveri in having four rooted M1; differing from $H$. daamsi, H. dispectus, H. thaleri, H. mediterraneus, H. peralensis, H. freudenthali, and H. adroveri in having incomplete ectolophs on the M1 and M2; differing from $H$. decedens, $H$. dispectus, $H$. thaleri, and $H$. aragonensis in lacking enamel coated valley on the M1-M2; differing from $H$. decedens, $H$. aguirrei, $H$. daamsi, H. dispectus, H. lavocati, H. thaleri, and H. aragonensis in lacking mesoloph on the M1; differing from Hispanomys castelnovi, $H$. dispectus, $H$. nombrevillae, $H$. thaleri, $H$. mediterraneus, $H$. peralensis, $H$. freudenthali, and $H$. adroveri in having the M3 much less reduced; differing from Hispanomys peralensis, $H$. freudenthali, and $H$. adroveri in having labial anterolophid in all $\mathrm{m} 1$; differing from all species of 
Hispanomys in having double metalophid on the $\mathrm{m} 1$ (some of them like $H$. decedens, $H$. aguirrei, $H$. lavocati, $H$. nombrevillae, $H$. mediterraneus, and $H$. baixasi have it in a major or minor part of the specimens, whereas in the remaining species it is absent) differing from $H$. adroveri in having very short or absent mesolophid on the $\mathrm{m} 1$; differing from $H$. aragonensis, $H$. thaleri, $H$. nombrevillae, and $H$. aguirrei in having the $\mathrm{m} 2$ three rooted; differing from $H$. nombrevillae, $H$. aguirrei, Hispanomys peralensis, $H$. freudenthali, and $H$. adroveri in having the $\mathrm{m} 3$ much more reduced.

\section{1. Description}

M1: These teeth show a pronounced groove between the two lobes of the anterocone. The anterolophule connects the lingual lobe of the anterocone with the protocone. There is a labial spur of the anterolophule in some specimens. The protosinus is partially closed by a large protostyle that can be connected to the anteroloph by a ridge. The anterior ectoloph is well_-developed; it is as high as the anterocone, and reaches or nearly reaches the anterior wall of the paracone closing the anterosinus. The fordward paracone spur is usually absent. The protolophule is anterolabially directed and it is oblique. The long and strong backward paracone spur connects to a more labially located branch (posterior ectoloph), which arises from the anterior wall of the metacone, closing the mesosinus. The backward paracone spur emerges from the midpoint of the protolophule and is generally posterolabially oriented. All specimens lack the mesoloph, but some of them have the beginning of the anterior arm of the hypocone somewhat inflated. They have no cingula surronding the labial valleys. The nearly transverse sinus is almost closed by a ridge, which emerges from the 
hypocone. Some specimens show entostyle and a vestigial entomesoloph. These teeth have short labial and lingual posteroloph. They have four roots.

M2: The occlusal outline of these teeth is sub-rectangular, longer than wide, with its posterior part somewhat rounded and narrower than the anterior one. They have a well-developpeddeveloped lingual anteroloph and a distinct protosinus in the anterior margin of the teeth. The labial anteroloph is absent. The anterior ectoloph and the forward paracone spur are usually absent, but on occasion they are en occasion-very low and tiny. Therefore, the anterosinus is generally open except in much worn specimens, in which it is closed. The paracone spur is long and strong, reaching a small anterior ridge of the metacone (posterior ectoloph) to entirely close the mesosinus. All teeth have the mesosinus larger than the anterosinus and they have no labial cingula surronding the valleys. A true mesoloph is lacking, but some specimens have the beginning of the anterior arm of the hypocone slightly inflated. The backward paracone spur is generally posterolabially oriented; it emerges from the midpoint of the protolophule from which it rises to reach the labial side of the tooth. Some specimens show a short lingual spur emerging from the backward paracone spur. The protolophule is oblique and anterolingually directed. The sinus is usually closed by the junction of a ridge that emerges from the anterior side of the hypocone with another that descend from the posterior margen of the protocone (vestigial entomesoloph) (e.g., FSL 66482, FSL 66276; Fig.4.8). These teeth show short labial and lingual posterolophs; the latter one is more developpeddeveloped than the former. These teeth have four roots.

M3: The occlusal outline of these teeth is rounded, longer than wide, with its posterior part narrower than the anterior one. The labial anteroloph is long and the lingual one is less developpeddeveloped, but distinct. The anterosinus is somewhat 
smaller than the mesosinus. The anterior ectoloph is lacking and the fordward paracone spur is small or even absent. The backward paracone spur is long; in some specimens it emerges from the midpoint of the protolophule from which it rises to reach the labial $\underline{\text { side of the tooth. It usually connects to the posterior ectoloph, closing the mesosinus, }}$ but in some specimens it is free because of the absence of the posterior ectoloph (e.g., FSL 66501). The nearly transverse protolophprotolophule connects to the junction between the posterior arm of the protocone and the anterior arm of the hypocone at about the centre of the tooth. These teeth usually have a long and distinct posteroloph but ocassionally the metacone may be fused with the posteroloph making the latter indistinct. The backward paracone spur is long, in some specimens it emerges from the midpoint of the protolophule from which it rises to reach the labial side of the tooth. It usually connects to the posterior ectoloph closing the mesosinus, but in some specimens it is free because of the absence of the posterior ectoloph (e.g., FSL 66501). The posterior side of the protocone generally has a strong ledge, which is directed towards the hypocone. This ledge comes into the sinus closing it partially. The sinus is very anterolabially directed. These teeth have three or four roots and they are not reduced. Actually, the value of the ratio mean LM1/mean LM3 of the teeth is very low, one of the lowest ones obtained for any Hispanomys species known to date (Tab. 2).

m1: The occlusal outline of these teeth is sub-rectangular, longer than wide, with its anterior part somewhat rounded and narrower than the posterior one. The labial anterolophid is long and prominent. It reaches the anterior side of the protoconid, closing thereby the protosinusid. Specimen 66284 has a protostylid that is joined with the anteroconid by a labial spur of the anterolophulid. The lingual anterolophid is weak (e.g., 66288, 66286) or absent. The metalophulid is double. The mesolophid is usually 
absent with some specimens showing a slight inflation at the end of the posterior arm of the protoconid, but it can be short (e.g., 66292). These teeth have usually no lingual cingula surrounding the valleys, but some of them (e.g., 66290, 66292, 66306, 66305) have it. Most of the teeth lack ectomesolophid, but in some of them (e.g., 66284) it is present. The sinusid is anterolingually directed. It is generally closed by the junction of two ridges; the first one emerging from the posterior wall of the protoconid and the second one from the anterior wall of the hypoconid. This ridge can bear an ectostylid. The posterosinusid is very small, but distinct. The posterolophid is long, but does not reach the posterior wall of the entoconid. These teeth are two-_rooted.

m2: These teeth are rectangular in shape, though they are anteriorly and posteriorly rounded. They show a prominent labial anterolophid that reaches the anterolabial side of the protoconid, closing the protosinusid. The metalophulid and the hypolophulid are anterolabially directed. These teeth have not lingual cingula surrounding the valleys. The mesolophid is short or of medium size and free and it can join with the posterior side of the metaconid. The nearly transverse sinusid is partially closed by two ridges; the first one emerging from the posterior wall of the protoconid and the second one from the anterior wall of the hypoconid.The posterolophid is long, but does not reach the posterior side of the entoconid. These teeth are three rooted.

m3: The occlusal outline of these teeth is rectangular, longer than wide, with its posterior part rounded and somewhat narrower than the anterior one. They show a long and strong labial anterolophid that connects to the anterior wall of the protoconid, closing the protosinusid. The lingual anterolophid is absent. The mesolophid is short or of medium size and it can be free or connected to the posterior wall of the metaconid. The posterosinusid and mesosinusid are open; there are no lingual cingula surrounding 
the valleys. The nearly transverse sinusid is partially closed by two ridges: the strongest emerges from the posterior wall of the protoconid ${ }_{2}$ whereas the other comes out from the anterior wall of the hypoconid. An ectostylid can be present (e.g., FSL 66372). The posterolophid is long, but it does not join with the posterior wall of the entoconid, and a labial posterosinusid is very weak or lacking. These teeth are three-_rooted.

\section{2. Comparisons}

3. 2.1. Comparison with-Hispanomys castelnovi Aguilar, Calvet et Michaux, 1994

Formatted: Left, Indent: First line: $0.2^{\prime \prime}$

\subsubsection{Historical background}

Formatted: Font: Italic

This species was erected on the basis of several lower and upper isolated molars

Formatted: Indent: First line: $0.2^{\prime \prime}$ from the MN6 locality of Castelnou 6 (Pyrénées-orientales, France). The holotype (CTN 6 nr. 54), a single m1, is housed at the USTL (Aguilar et al., 1994). According to these authors this locality is Middle Miocene in age. However, the degree of evolution Formatted: Not Highlight of the teeth of Hispanomys castelnovi, which incidentally comes from a fissure filling, may suggests a younger age.

\subsubsection{Comparison with H. bijugatus}

The cheeck teeth of $H$. bijugatus are larger than those of $H$. castelnovi. In addition,

the M1 and M2upper molars of this species lack the entomesoloph ${ }_{2}$ and the M3 has no old entoloph-whereas these structuresa vestigial entomesoloph are-is present in some

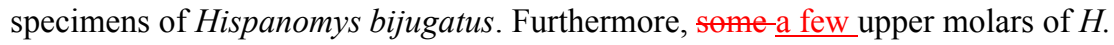
castelnovi have a low labial cingulum (Aguilar, pers. comm. 2009), whereas none of those of $H$. bijugatus has it. One of the most remarkables differences between these taxa is the absence of a double metalophulid on the $\mathrm{ml}$ of $H$. castelnovi. This structure is always present on the $\mathrm{m} 1$ of $H$. bijugatus. 
3. 2.2. Comparisen with-Hispanomys decedens (Schaub, 1925)

\subsubsection{Historical background}

This species was initiallyerected by Schaub (1925: p. 13) as Cricetodon sansaniense Lartet, 1851 var. decedens. Later on, this author raised this variety to the species level (Schaub, 1944: p. 454). Mein and Freudenthal (1971: p. 19) introduced the subgenus Hispanomys for a handful of supposedly derived Cricetodon. This subgenus was elevated to the genus level by Van de Weerd (1976: p. 106 et seq.).

- The holotype of this species $(\operatorname{Lgr} 130)$, a left maxillary fragment with M1 and M2, comes from the $\underline{a}$ MN7/8 unnamed $\&$ fissure-filling toeality M-of La Grive-Saint Alban (Isère, France). It is housed in the MSNL. Alba et al. (2006) and Casanovas-Vilar (2007) mentioned the existence of additional material of Hispanomys decedens from various MN7/8 sites of the Can Mata series (Barcelona).

Alba et al. (2006) and Casanovas-Vilar (2007) mentioned the existence of additional material of Hispanomys decedens from the MN7/8 locality of Hostalets de Pierola (Barcelona, Spain).3.2.2.2. Comparison with H. bijugatus

The M1 and M2 of $H$. decedens show low labial cingula surrounding the valleys (absent in H. bijugatus). The upper molars of $H$. decedens have usually a mesoloph, which is absent on those of $H$. bijugatus, and the ectolophs are less developed than in the latter species. With regard to the lower molars, the percentage of $\mathrm{m} 1 \mathrm{with}$ a double metalophulid in $H$. decedens is lower than in H. bijugatus. In contrast, there are more $\mathrm{m} 1$ with ectomesolophid in H. decedens than in H.bijugatus. The lingual anterolophid is usually more developpeddeveloped on the $\mathrm{m} 1$ of $H$. decedens than in those of $H$.
Formatted: Font: Not Italic

Formatted: Font: Italic

Formatted: Font: Italic

Formatted: Indent: First line: $0.2 "$

Formatted: Font: Not Italic 
bijugatus. Some $\mathrm{m} 3$ of $H$. decedens have the mesolophid long , $_{2}$ the $\mathrm{m} 3$-whereas it is short or of medium size in H. bijugatus.

\section{2.3. Comparison with Hispanomys aguirrei (Sesé in López-Martinez, Sesé et $\underline{\&}$} Sanz-García, 1977)

\subsubsection{Historical background}

This taxon was initially named Cricetodon aguirrei by Sesé in López-Martinez et al. ^

1977) and posteriorly reallocated by Agustí (1977a: p. 31) to the genus Hispanomys.

The holotype (ES-221/224) is a left maxillary fragment with M1-M2 (kept in the collections of the MNCN) from the Middle Miocene (MN 7/8) locality of Escobosa I,

Escobosa de Catalañazor(Soria, Spain). Additional material of this species has been found at the coeval localities Escobosa-M and Escobosa G-2 (Sesé in López-Martinez, Sesé \& Sanz-García, 1977) and recently at the Upper Aragonian locality of Nombrevilla

2_(Saragossa, Spain) (López Guerrero et al., 2008).

Formatted: Font: Not Italic

\subsubsection{Comparison with $\mathrm{H}$. bijugatus}

About a quarter of the $\mathrm{m} 1$ of Hispanomys aguirrei shows a double metalophulid, whereas all $\mathrm{m} 1$ of $H$. bijugatus have it. Most of the $\mathrm{m} 2$ of $H$. aguirrei have two double roots, whereas those of $H$. bijugatus already are three rooted. The $\mathrm{m} 3$ of $H$. aguirrei from Escobosa are smaller than those of $H$. bijugatus. With regard to the upper molars, most of the M1 and M2 of $H$. aguirrei have well_-developpeddeveloped low cingula closing the labial valleys, some of them have mesoloph and lack entomesoloph. In contrast, both the labial cingula and the mesoloph are always missing on the M1 and M2 of $H$. bijugatus, and some of them have an entomesoloph. Even if the M3 of $H$. aguirrei are not much reduced, the value of the ratio mean LMI/mean LM3 is higher in 
this species than in H. bijugatus, which shows that a degree of reduction in the former taxon (Tab. 2). In addition, some all the-M3 of H. aguirrei tack the old entoloph and some of them have a mesoloph, whereas some of thethe mesoloph is missing on all -M3 of $H$. bijugatus have old entoloph and the mesoloph is missing on all of them.

3.2.4. Comparison with Hispanomys daamsi Agustí, Casanovas-Vilar et Furió, 2005

\subsubsection{Historical background}

Formatted: Font: Italic

The holotype of this species (IPS 16444), a left mandible with m1-m3, is housed at

Formatted: Indent: First line: $0.2^{\prime \prime}$ the IPS. The This species was erected on the basis of several teeth recovered from the late Aragonian (MN 8) locality of Can Missert (Vallès-Penedès Basin, Barcelona, Spain)-(Agustí et al., 2005). Further material of this taxon has been recently reported from MN7/8 levels at Hostalets de Pierola, Barcelona, España (Alba et al., 2006; Casanovas-Vilar, 2007).

\subsubsection{Comparison with $\mathrm{H}$. bijugatus}

The cheeck teeth of $H$. daamsi are larger than those of $H$. bijugatus. The M1 and M2 Formatted: Indent: First line: $0.2^{\prime \prime}$ of $H$. daamsi show small cingula at the base of the labial valleys and lack the entomesoloph ${ }_{2}$ whereas the labial cingula are missing in the M1 and M2 of H. bijugatus and some of them have the entomesoloph. Even if the M3 are not much reduced in $H$. daamsi, this taxon has a mean LMI/mean LM3 ratio higher than H. bijugatus (Tab. 2). In addition, all the M3 of $H$. daamsi lack the olda vestigial entomesoloph, entoloph whereas it is present on some M3 of H. bijugatus. With respect to the lower molars, the $\mathrm{m} 1$ of $H$. bijugatus have a double metalophulid, which is single on those of $H$. daamsi.The $\mathrm{m} 3$ of $H$. daamsi usually show a better developed mesolophid than those of H. bijugatus. 
3.2.5. Comparison with-Hispanomys dispectus Agusti, 1980a

\subsubsection{Historical background}

This species was first cited by Agustí and Gibert (1979: pp. 17-18), but in a way that does not fulfil the requirements for the name to be considered as available (International Commission on Zoological Nomenclature, 1999, article 13.1). In particular, the short description does not provide characters purported to differentiate the taxon. The valid description of this taxon is provided by Agustí (1980a) as explicitly mentioned by Agustí and Gibert (1979: p. 17).

According to Agustí (1980ạ: p. 56), the material from Hostalets de Pierola described by Schaub $(1944,1947)$ and listed by Crusafont and Casanovas (1973) as Cricetodon decedens would pertain to Hispanomys dispectus. In addition, in the same work, this author stated that $H$. cf. thaleri from Castell de Barbera (Aguilar et al., 1979) and from La Bisbal I and La Bisbal II, Gerona, Spain (Gibert et al., 1980) pertains actually to $H$. dispectus.

The holotype of Hispanomys dispectus (IPS VP 610) is a complete left maxilla from a lower level (MN 8) of the Hostalets de Pierola locality-(Vallès Penedès). Additional material of this species has been also recovered from the Vallès Penedès at the sites of Hostalets de Pierola (upper levels, MN 9), Can Feliu (MN 7/8), Castell de Barbera (MN 8), and Creu Conill 22 and 20 (MN 9) as well as from Ampurdá (Gerona) at the MN 9 locality of La Bisbal II (Agustí, 1980ạ, 1981; Gibert et al., 1980; Casanovas-Vilar et al., 2006).

\subsubsection{Comparison with $\mathrm{H}$. bijugatus}

Formatted: Font: Not Italic

Formatted: Font: Italic

Formatted: Indent: First line: $0.2 "$ 
This species differs from $H$. bijugatus in having labial valleys surrounded by low

Formatted: Indent: First line: $0.2 "$ cingula on the upper molars, and, tstally in some specimens, quite well--developed mesolophs, which are absent on the upper molars of $H$. bijugatus. The value of the mean LM1/mean LM3 ratio of the teeth of $H$. dispectus is higher than that calculated for H. bijugatus, which has therefore the $\mathrm{m} 3$ less reduced (Tab. 2). With regard to the lower molars, the m1 Hispanomys dispectus lack the double metalophulid, which is present in all $\mathrm{m} 1$ of $H$. bijugatus.

3.2.6. Comparison with Hispanomys lavocati (Freudenthal, 1966)

\subsubsection{Historical background}

Formatted: Font: Italic

This taxon was erected by Freudenthal (1966) as a species of Cricetodon. Subsequent

Formatted: Indent: First line: $0.2^{\prime \prime}$ authors (Agustí, 1977a: p. 31 et seq.) reallocated it to the genus Hispanomys, an act with which we agree. The holotype of this species (VP 536), a complete left maxilla from the lower levels (MN 8) of the Hostalets de Pierola locality-(Vallès-Penedès), is housed in the IPS. Additional material of this taxon -has been also recovered in the coeval locality of Sant Quirze, Barcelona, Spain (Agustí, 1977b) and Nombrevilla 2, Saragessa, Spain (López-Guerrero et al., 2008). The material from Viladecavalls described by Schaub (1947: p. 62) as C. decedens and reallocated to H. lavocati by Freudenthal (1966: p. 313), actually belongs to H. thaleri (Agusti, 1980: p. 59).

\subsubsection{2 . Comparison with $\mathrm{H}$. bijugatus}

-Hispanomys lavocati is larger than H. bijugatus. With regard to the upper molars, the M1 and M2 of $H$. lavocati have labial cingula surrounding the valleys and ${ }_{2}$ on occasions, a short mesoloph, both of which are absent on the upper molars of $H$. bijugatus. In addition, some the-M3 of $H$. lavocati have a moderately long mesoloph, 
which is lacking in H. bijugatus. With regard to the lower molars, those of H. lavocati

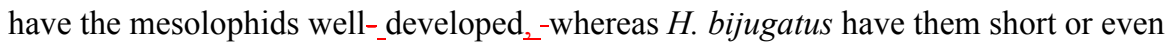
absent. Furthermore, the $\mathrm{m} 1$ of $H$. lavocati have a single metalophid,-whereas it is double in those of $H$. bijugatus. Most The $\mathrm{m} 2$ of $H$. lavocati have two double roots, whereas those of $H$. bijugatus are three-rooted.

\subsubsection{Comparison with Hispanomys nombrevillae (Freudenthal, 1966)}

\subsubsection{Historical background}

Freudenthal (1966) created the subspecies Cricetodon decedens nombrevillae. Later on, in their classification of the Cricetidae, Mein and Freudenthal (1971) reallocated it in the subgenus Hispanomys. According to them, most of the Can Llobateres material assigned to Ruscinomys thaleri by Hartenberger (1965) would pertain to that taxon (see discussion below). The holotype of $H$. nombrevillae (NO 258) is a single M1 from the lower Vallesian site (MN9, H) of Nombrevilla_(Saragessa). It is housed in the IPS. Additional material of this species has been recovered from a tower Vallesian (MN 9) locality near Molina de Aragón,-Guadalajara, Spain (Lacomba, 1988).

\subsubsection{Comparison with $\mathrm{H}$. bijugatus}

The size of the cheek teeth of Hispanomys nombrevillae is smaller than in $H$. surrounding the valleys; these cingula are absent on the upper molars of $H$. bijugatus. The M3 of $H$. nombrevillae are much reduced, being the values of the ratio mean LM1/mean LM3 of its teeth very high, whereas it is very low in H. bijugatus, which has not the third upper molars reduced (Tab. 2). With regard to the lower molars, none of the $\mathrm{m} 1$ of $H$. nombrevillae has a double metalophulid ${ }_{2}$ whereas it is present in all $\mathrm{m} 1 \mathrm{of}$ 
$H$. bijugatus. The $\mathrm{m} 2$ of $H$. nombrevillae have two double roots, whereas those of $H$. bijugatus are three-rooted.

3.2.8. Comparison with Hispanomys thaleri (Hartenberger, 1965)

3.2.8.1. Historical background

Hartenberger (1965) erected the new species Ruscinomys thaleri on the basis of cheek teeth from the MN 9b locality of Can Llobateres-(Barcelona, Spain). Later on, Mein and Freudenthal (1971) discussed the status of $R$. thaleri. According to them, the holotype of this species would be a true Ruscinomys, but most of its paratypes would correspond to Cricetodon Hispanomys cf. nombrevillae. The comparison of the Vallesian material of Can Ponsic with that of Can Llobateres by Agustí (1984) led him to consider $H$. thaleri a homogeneous population, to which an emended diagnosis was given. This species has been also recovered from the MN 9 localities of Rubí- Terrassa6E, Can Ponsic, and Riu Ripoll (Barcelona, Spain), and the MN 10 localities of Can Casablanques, Camí de Can Tarumbot-2, Rubí- Terrassa-7, Viladecavalls, Torrent de Febulines, Trinxera Sur Autopista II, Trinxera Nord Autopista II, and Can Jofresa, Barcelona, Spain (Agustí, 1981; Agustí and Gibert, 1982; Agustí et al., 1997). The holotype of $H$. thaleri (CL3630) is a single M1 housed at the IPS (Hartenberger, 1965).

\subsubsection{Comparison with $\mathrm{H}$. bijugatus}

One of the differences between the two taxa is the presence of the enamel-coated

$$
4
$$

Formatted: Indent: First line: $0.2^{\prime \prime}$

valley. Even if only few upper molars of $H$. thaleri have it, none of $H$. bijugatus show this structure. In addition, the M3 of $H$. thaleri are noticeably less reduced than those of

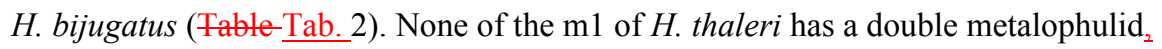
whereas it is present in all $\mathrm{m} 1$ of $H$. bijugatus. The $\mathrm{m} 2$ of $H$. thaleri have two roots, 
whereas those of $H$. bijugatus are three-rooted. Finally, the $\mathrm{m} 3$ of $H$. thaleri are less reduced than those of $H$. bijugatus.

3.2.9. Comparison with Hispanomys aragonensis (Freudenthal, 1966)

\subsubsection{Historical background}

This species was originally erected as Cricetodon decedens aragonensis by

Freudenthal (1966). Subsequently, Mein and Freudenthal (1971) reallocated it in the subgenus Hispanomys.

- The holotype of this species (PEC 1164), an isolated M1 from the lower Vallesien $\left(\mathrm{MN}_{2} \mathrm{I}\right)$ locality of Pedregueras IIC-(Saragossa, Spain), is housed in the IPS.

Additional material has been recovered from the MN 9b (I) localities of Pedregueras 1A and 2A (Freudenthal, 1966). Two teeth of this species have been also reported from the MN9a (H) locality of Los Valles de Fuentidueña, Segovia, Spain (Agustí, 1978: p. 139).

\subsubsection{Comparison with $\mathrm{H}$. bijugatus}

The upper molars of Hispanomys aragonensis have labial cingula surrounding the valleys, which are lacking on the upper molars of $H$. bijugatus. Some of the M1 and M2 of Hispanomys aragonensis have a small enamel-coated valley in the occlusal surface of the paracone, whereas it is absent in all M1 and M2 of H. bijugatus. The M3 of Hispanomys aragonensis are less reduced than those of H. bijugatus (Tab. 2). With regard to the lower molars, some of those of Hispanomys aragonensis have a lingual cingulum surrounding the valley, whereas it is lacking on those of H. bijugatus. With regard to the lower molars, some $\mathrm{m} 1$ of $H$. aragonensis show two short mesolophids The $\mathrm{m} 1$ of Hispanomys aragonensis have a single anterolophid, -whereas there is only one $^{-}$ or none on the $\mathrm{m} 1$ of $H$. bijugatus. The metalophulid is single in H. aragonensis,
Formatted: Font: Italic

Formatted: Indent: First line: $0.2^{\prime \prime}$ 
whereas it is whereas it is double on the-all $\mathrm{m} 1$ of $H$. bijugatus. In addition, some $\mathrm{m} 1$ of H. aragonensis have a lingual anterolophid, which is lacking on the $\mathrm{m} 1 \mathrm{of} H$. bijugatus.

Finally, the $\mathrm{m} 2$ of $H$. aragonensis have two roots (with the posterior one being splited), whereas those of $H$. bijugatus are three-rooted.

3.2.10. Comparison with Hispanomys mediterraneus Aguilar, 1982

\subsubsection{Historical background}

Formatted: Font: Italic

Aguilar (1982) created this species on the basis of isolated cheek teeth from the Late

Miocene (MN 10) site of Montredon, Hérault, France. He gave a list of chresonyms, in which he states that (at least) a part of the material studied by Hartenberger (1965) and attributed to the species Ruscinomys thaleri and, therefore-thereby (see discussion on $H$. thaleri above) Hispanomys cf. nombrevillae (incorrectly mentioned in the text as $H$. cf. aragonensis) discussed by Mein and Freudenthal (1971), pertained in fact to $H$. mediterraneus. However, the comparison of the Vallesian material of $H$. thaleri from Can Ponsic with that from Can Llobateres carried out by Agustí (1984) led him to consider H. thaleri a homogeneous population and invalidate this supposition. In addition, in the same list of chresonyms, Aguilar (1982) stated that the material from Montredon described by Thaler (1966, p. 151, Fig. 21E) as Cricetodon (Cricetodon) cf. decedens (and later on listed by Guérin and Mein (1971: p. 149) and figured by Enguesser (1972: pp. 288, 292)) as well as that described and figured as Cricetodon sp. 1 by Hartenberger and Thaler (1963: pp. 3333-3335) would also belong to $H$. mediterraneus.

The holotype of this species (MTN nr. 1509) is a single left M1 housed at the USTL. Additional material of this species has been recovered from the Upper Vallesian and 
lower Turolian-localitiesy of Lo Fournas 7 (Aguilar, Escarguel \& Michaux, 1999). The Turolien material of $H$. mediterraneus from Lo Fournas 6, as well as, that of $H$. cf. mediterraneus from Castelnou 1 and Castelnou 3 has been recently attributed to $H$. baixasi (Aguilar et al., 2007). and Lo Fournas 6, Pyrénées-orientales, France (Aguilar et al., 1999). Besides, Hispanomys cf. mediterraneus has been reported from the Turolien localities of Castelnou 1 and Castelnou 3, Pyrénées-orientales, France (Aguilar et al., 1999)-Mein (1999) mentioned the presence of $H$. mediterraneus at the MN 10 French localities of Soblay (Ain)-and Dionay, (Isère)-as well as $H$. cf. mediterraneus-, at the coeval localities of Ambérieu 1 and 2 (Ain).

\subsubsection{Comparison with $\mathrm{H}$. bijugatus}

_ The M1 and M2 of Hispanomys mediterraneus have the ectolophs more developpeddeveloped than those of $H$. bijugatus. In addition all M1 of the former species lack a labial spur of the anterolophule, which is present on some specimens of H. bijugatus. The M2 of Hispanomys mediterraneus have a much less developpeddeveloped lingual cingulum than those of $H$. bijugatus. With respect to the M3, those of H.mediterraneus are much reduced, whereas those of $H$. bijugatus are not that lessened (Tab. 2). With regard to the lower molars, none of the $\mathrm{m} 1$ of Hispanomys mediterraneus, but one, has double metalophulid ${ }_{2}$ whereas all $\underline{\mathrm{m} 1}$ of $H$. bijugatus have it. The $\mathrm{m} 2$ and $\mathrm{m} 3$ of $H$. mediterraneus usually have the mesolophid less developpeddeveloped than those of $H$. bijugatus.

3.2.11. Comparison with Hispanomys peralensis Van de Weerd, 1976 
Van de Weerd (1976) erected the species Hispanomys peralensis based on material from the MN 10 locality of Peralejos $\mathrm{C}$ and assigned to this species material from other MN 10-11 localities of the Teruel-Alfambra region, Spain (Masia del Barbo 2A, Masía del Barbo 2B, Peralejos B, Peralejos D and Peralejos 4)(Peralejos D, Peralejos B, Peralejos 4, Masia del Barbo 2B, and Masía del Barbo 2A). The holotype (PERC 351) is an isolated M1 from the locality Peralejos C (Van de Weerd, 1976), which is correlated to the local subzone J3 (MN 10) of Van Dam et al. (2001). It is stored in the collection of the RUU. According to Van de Weerd (1976), the two species of Cricetodon from Masia del Barbo 2A and 2B described by Freudenthal (1966: pp. 308310), but not named, also pertain to H. peralensis. Antunes and Mein (1979: p. 916) mentioned the presence of $H$. peralensis from the lower MN 10 site of Freiria de Rio Maior, Portugal. Freudenthal, Lacomba and Martín-Suárez (1991: p. 11) pointed out that the material from the MN 11 locality of Tortajada A (Teruel-Alfambra region), described as H. freudenthali by Van de Weerd (1976), as well as that from the MN 11 localities of Crevillente 1, 3 and 4 (Alicante, Spain) designed by De Bruijn et al. (1975: p. 297) as H. sp. A, also correspond to $H$. peralensis. More material of $H$. peralensis from this zone has been recovered at the localities Crevillente 2 and Crevillente 4B (Freudenthal et al., 1991). Alcalá et al. (2005, p. 201, Fig. 3) reported H. peralensis at the MN10-J3 localities MR604-A and B and H. cf. peralensis at MR604-B, Masía de la Roma, Teruel, Spain. Furthermore, van Dam et al. (2001) listed H. peralensis at various MN9 (I) and MN 10 localities of the Teruel-Alfambra region (Peralejos 5, Masía de la Roma 3, Masía de la Roma 4B, Masía de la Roma 4C, Masía de la Roma 6, Masía de la $\underline{\text { Roma 7, Masía del Barbo A, Masía de la Roma 9, Peralejos 4, Masía del Barbo B, }}$ Puente Minero 8, Puente Minero 10, Masada Ruea, and Peralejos C). In addition, they
Formatted: Indent: First line: $0.2^{\prime \prime}$

Formatted: Font: Not Italic

Formatted: Font: Not Italic

Formatted: Font: Not Italic 
mentioned the co-occurrence of this species and $H$. aff. peralensis at some of them

(Peralejos 5, Masía de la Roma 3, Masía de la Roma 4C, Masía de la Roma 7, Masía del

Barbo A, Peralejos 4, and Masía del Barbo B). Finally, van Dam et al. (2001)

Formatted: Font: Not Italic mentioned other localities where either $H$. peralensis or $H$. aff. peralensis is present

(Masía de la Roma 4B, Masía de la Roma 6, Masía de la Roma 8, Masía de la Roma 9

La Salle, Masía de la Roma 11, and Los Aguanaces 5A). Furthermore, Van Dam et al. (2001) listed $H$. peralensis at various MN 10 localities of the Teruel-Alfambra region

(Masía de la Roma 4C, 6, and 7, Puente Minero 8, 10, and Masada Ruea 2A). They alse mentioned $H$. cf. peralensis at Masía de la Roma 5, 8, 9, 11, La Salle, Peralejos A, La Gloria 14A/B, and Los Aguanaces 4, 5A, 5B.Besides, two m1 identified as $H$. cf. peralensis have been recovered from two MN10 localities (CRS2A and CR S2B) of the Cortasogas site, Calatayud Basin, Spain (Van Dam and Sanz Rubio, 2003). On the basis of very poor material (two isolated teeth and three fragments), Calvo et al. (1978) Formatted: Font: Not Italic recognized $H$. cf. peralensis at the MN10 locality of Hijar-1, Albacete, Spain. $H$. cf. peralensis has been also cited from the MN11 site of Lobrieu, Vaucluse, France (Mein, 1999).

\subsubsection{Comparison with $\mathrm{H}$. bijugatus}

The M1 of Hispanomys peralensis are four or five rooted ${ }_{2}$ whereas those of $H$. Formatted: Spanish (International Sort) Formatted: Font: Not Italic, Spanish (International Sort)

Formatted: Spanish (International Sort) bijugatus are four rooted. In addition, none of the M1 of H. peralensis has either labial spur on the anterolophule or entomesoloph, and all of them have a distinct fordward paracone spur and a weak lingual cingulum. In contrast, some of the M1 of H. bijugatus have a labial spur on the anterolophule and an entomesoloph, they usually lack the fordward paracone spur and have a strong lingual cingulum. Furthermore, the M2 of $H$. peralensis have the lingual cingulum less developpeddeveloped than those of $H$. 
bijugatus and none of them have entomesoloph, whereas some of the M2 of $H$. bijugatus show a vestigial entomesoloph. The M3 of $H$. peralensis are much more reduced than those of $H$. bijugatus (Tab. 2) and they lack the posterior cingulum. This posterior cingulum is well developed and almost always present on the M3 of $H$. bijugatus, in which it emerges from the protocone reaching the posterior wall of the metacone. With regard to the lower molars, none of the $\mathrm{m} 1$ of $H$. peralensis has the double metalophulid, which is always present on the $\mathrm{m} 1$ of $H$. bijugatus. Finally, the $\mathrm{m} 2$ and $\mathrm{m} 3$ of $H$. peralensis have the mesolophid usually less developpeddeveloped than those of H. bijugatus.

3.2.12. Comparison with Hispanomys baixasi Aguilar, Michaux et Lazzari, 2007

\subsubsection{Historical background}

This species has been erected on the basis of mandibles, maxillae, and numerous Formatted: Font: Italic isolated cheek teeth from the Turolian locality of Lo Fournas 16-M, Pyrénées-

Orientales, France. Its holotype (Fou 16-M nr. 193) is a left M1. Further material of this species has been recovered at the coeval localities of Lo Fournas 6, Castelnou 1, and Castelnou 3, Pyrénées-Orientales, France (Aguilar et al., 2007).

\subsubsection{Comparison with $\mathrm{H}$. bijugatus}

Only few $\mathrm{m} 1 \mathrm{of} H$. baixasi show a double metalophulid, whereas it is always present on the $\mathrm{m} 1$ of $H$. bijugatus. The $\mathrm{m} 2$ of H. baixasi show less developed mesolophid than in $H$. bijugatus. In addition, the $\mathrm{m} 3$ of $H$. baixasi are more reduced than those of $H$. bijugatus. With regard to the upper molars, those of $H$. baixasi have the ectolophs usually more developed than those of H. bijugatus and they lack the entomesoloph, which is present on some M1-M2 of H. bijugatus. The M3 of H. baixasi are much more 
reduced than those of $H$. bijugatus and they lack the posteroloph, which is well developpeddeveloped on the M3 of $H$. bijugatus.

3.2.13. Comparisons with-Hispanomys freudenthali Van de Weerd, 1976

\subsubsection{Historical background}

The validity of the species Hispanomys freudenthali from the MN12 locality of Masada del Valle 2, Teruel Alfambra region, Spain, was discussed by Freudenthal, Lacomba and Martín-Suárez (1991). According to these authors, the holotype of this species (MDV2-1241), one M1 housed in the RUU, can be distinguished neither by the morphology nor by the size from a M1 of Pseudoruscinomys schaubi. Consequently, according to Freudenthal et al. (1991), the nominal taxon H. freudenthali should be considered a junior synonym of $P$. schaubi. Freudenthal et al. (1991) pointed out that the specimen MDV2-1212, one m2, should be also attributed to $P$. schaubi. Incidentally, Pseudoruscinomys is considered a synonym of Ruscinomys by Agustí (1980), who judges that $H$. freudenthali should be accommodated into the genus Ruscinomys. According to Freudenthal et al. (1991), the specimen (MDV2-1217), one $\mathrm{m} 2$, together with some $\mathrm{m} 3$ from the same locality would pertain in fact to $H$. adroveri. The remaining material considered as H. freudenthali by Van de Weerd (1976) should be allocated to a new species, to which would also belongs the material from the MN

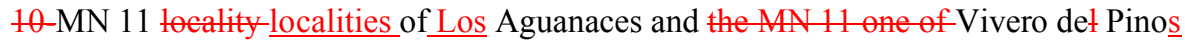
described as $H$. freudenthali by Adrover (1986). The presence of this taxon has been mentioned by Alcalá et al. (1991) at the early Turolian (MN 11) locality of Puente Minero (Teruel, Spain). Furthermore, Van Dam et al.(2001) listed H. freudenthali at various MN12 (Masada Ruea 4, Masada Ruea 3, Masada del Valle 2, Los Mansuetos 2.
Formatted: Font: Italic

Formatted: Indent: First line: $0.2^{\prime \prime}$

Formatted: Font: Not Italic

Formatted: Spanish (International Sort)

Formatted: Font: Not Italic, Spanish (International Sort)

Formatted: Spanish (International Sort) 
Tortajada B), MN11 (Valdecebro 4, Vivero de Pinos, Tortajada A, Los Aguanaces 3,

Los Aguanaces, Regajo 2, Puente Minero 3, La Gloria 10, Masada Ruea 2, Puente

Minero, Peralejos D) and MN10 (J3) (Los Aguanaces 6) localities from this area.

\subsubsection{Comparison with $\mathrm{H}$. bijugatus}

The teeth of $H$. freudenthali are larger and more hypsodont than those of $H$.

bijugatus. The M1 of the former species have usually five roots, whereas those of $H$.

bijugatus always are four-rooted. In addition, the lingual cingulum is much less stronger on the M1 of $H$. freudenthali than in those of H. bijugatus and they lack the entomesoloph, which is present on some M1 and M2 of H. bijugatus. The M3 of $H$.

freudenthali are much reduced, being the mean LM1/mean LM3 ratios very high, whereas they are very low in $H$. bijugatus, which has not the third upper molars reduced at all (Tab. 2). Therefore, on the M3 of H. freudenthali the anteroloph, anterior ectoloph, and fordward paracone spur are totally fused with the protocone and the paracone, the sinus is usually very small or absent, and the posteroloph is lacking. In contrast, the $\mathrm{M} 3$ of $H$. bijugatus have a long anteroloph not connecting with the paracone, a quite large sinus, and a well_developpeddeveloped posteroloph. With regard to the lower molars, the $\mathrm{m} 1$ of $H$. freudenthali have a single metalophid, which is double in H. bijugatus; about half the individuals lack the anterolophid on the lower molars, which is always present in H. bijugatus.

3.2.14. Comparison wispanomys adroveri Agusti, 1986 

(MN 12) locality of Casa del Acero, Fortuna Basin, Murcia, Spain. It is housed in the IPS. This species has been also recorded from the coeval locality of Crevillente 15, Alicante, Spain (Freudenthal et al., 1991). Additional material of this taxon has been recovered from the Late Turolian (MN 13) Librilla section (BS-141), Fortuna Basin, Cuenca de Fortuna, Murcia, Spain(Agustí et al., 1999, 2006). In addition, material attributed to Hispanomys aff. adroveri has been recovered from other Late Miocene localities of Crevillente $(5,8,14,17)$ (Freudenthal et al., 1991) and from the coeval locality of Canteras de Jun, Granada, Spain (García-Alix et al., 2008). According to Freudenthal et al. (1991), this taxon would be also represented in the MN 12 locality of Masada del Valle 2, Teruel-Alfambra region, Spain (see $\S$ on “ $H$. freudenthali”).

\subsubsection{Comparison with $\mathrm{H}$. bijugatus}

This species is much larger and hypsodont than H. bijugatus. The M1 of Hispanomys adroveri are five rooted ${ }_{2}$ whereas they are four rooted in $H$. bijugatus. Other differences between the two taxa include the more marked development of the ectolophs on the upper molars of $H$. adroveri, particularly on the M2, in which both labial valleys are closed (on the M2 of H. bijugatus, the anterosinus remains usually open due to the absence of the fordward paracone spur). The M3 of $H$. adroveri are much reduced; they lack the posteroloph, have the sinus connected to the anterosinus and mesosinus and about half the specimens lack the protolophprotolophule (the paracone being isolated). In contrast, the M3 of $H$. bijugatus are not reduced, the posteroloph is well_developed, the three sinuses are unconnected, and the protolophprotolophule is well_developed. With regard to the lower molars, those of $H$. adroveri lack double metalophid and they show a well-developed mesolophid that normally joins with the metaconid ${ }_{2}$ whereas in 
$H$. bijugatus the metalophid is always double and the mesolophid usually absent. In addition, the $\mathrm{m} 2$ of $H$. adroveri lack the protosinusid ${ }_{2}$ whereas it is present on the $\mathrm{m} 1$ of H. bijugatus.

\subsubsection{Comparison with-Hispanomys lusitanicus (Schaub, 1925)}

This species was originally attributed to the genus Cricetodon by Schaub (1925) and reallocated to the subgenus Hispanomys by Mein and Freudenthal (1971). This taxon is based on one incomplete mandible with m1-m2 (unnumbered, MGISTL), which is supposed to come from the late Miocene (MN 10) of Carvalhal Novo (Azambujeira, Portugal). According to Antunes (1984), the holotype is damaged, not characteristic enough, and the taxon is badly-defined so that its validity is questionable. Pending a revision, this taxon is not considered in the present study.

\section{Discussion}

From the Upper Aragonian six Seven taxa belonging to the genus Hispanomys are known from Upper Aragonian strata: H. castelnovi, H. decedens, H. bijugatus, $H$. aguirrei, H. daamsi, H. dispectus, and H. lavocati.- During the Upper-Late Aragonian and Lower Early Vallesian, the main source of morphological variability are the different development of the ectolophs, the presence or absence of mesolophs and mesolophids, the existence of cingular structures in the upper and lower molars, and the increase in the number of roots in second molars (Agustí, 1981, 1982). Despite these morphological differences, the general pattern of the cheek teeth is rather homogeneous within each population. The most primitive morphologies are characterized by having 
lower molars with well--developed labial anterolophids, with lingual anterolophids, with lingual cingula surrounding the valleys, with vestigial ectomesolophid on the $\mathrm{m} 1$, two rooted $\mathrm{m} 2$, and unreduced $\mathrm{m} 3$. On the other hand, the most primitive upper molars are characterized by having mesolophs, labial cingula surrrounding the valleys, quite incomplete ectolophs,, -vestigial entomesoloph ${ }_{2}$ and old enteloph,-four rooted M1, and unreduced M3.

From La Grive-Saint Alban two species of Hispanomys have been recovered, $H$. bijugatus and H. decedens. The first taxon has been found in La Grive-Saint Alban at localities L3 and L5, whereas H. decedens has been recovered at localities L3 and L7 $\underline{\mathrm{L} 5}$, as well as from LaGrive-Saint Alban-M, and at the unnamed fissure-filling.

The age of the different fissure-fillings of La Grive-Saint Alban is controversial. According to Mein and Ginsburg (2002), the oldest localities would be La Grive M and L7, which were correlated to the MN7, whereas the youngest ones would be La Grive L3 and L5, which they correlated with MN8. On the contrary, Maridet (2003: p. 197) pointed out that La Grive L3 and L5 would be actually the oldest of La Grive localities, being followed by L7 and finally by M, which would be the youngest one.

If we compare the degree of evolution of the teeth in Hispanomys bijugatus and in $H$. decedens, it appears that the former shows a more progressive dental morphology. $H$. bijugatus has indeed the following derived characters, which are lacking in $H$. decedens: 1-) absence of labial and lingual cingula surrounding the upper and lower molar valleys respectively, 2-) absence of mesoloph on the upper molars, 3-) ectolophs more developpeddeveloped, 4-) lower percentage of $\mathrm{m} 1$ showing vestigial ectomesolophid, 5) less important development of the lingual anterolophid on the m1, and 6-) less marked development of the mesolophid on the $\mathrm{m} 3$. 
All these differences suggest that Hispanomys bijugatus is more derived than $H$. decedens. Because these species are believed to be closely related species within the same lineageTherefore (Mein \& Freudenthal, 1971: fig. 1; Chaline \& Mein, 1979: fig. 33; Agustí, 1980:fig. 4; Aguilar, 1982: fig. 6), La Grive M and L7 (both-with $H$. decedens only) may be older than La Grive L3 and L5 (with H. bijugatus), as suggested by Mein and Ginsburg (2002). The same is true for the unnamed fissure-filling. The coexistence of the two species at La Grive L3-L5 may indicate an older age for this locality than for $\mathrm{L} 5 \underline{\mathrm{L} 3}$, at from which only $H$. bijugatus has been recovered. As mentioned above, Mein and Ginsburg (2002) did not take into account the two M3 of $H$. decedens found in L7. Interestingly enough, should the presence of $H$. decedens in L7 not be due to "contamination", this locality (as La Grive M) may be older than La Grive L3 and L5 as also suggested by Mein and Ginsburg (2002).

\section{Conclusion}

The species Hispanomys bijugatus from La Grive-Saint Alban shows a low variability as common in the populations of Hispanomys from the Upper Aragonian. .Even if Hispanomys bijugatus have some of the typically primitive dental characters of the Aragonian species of Hispanomys, such as the not reduced M3, it shows a lot of progressive characters. These are: the absence of labial and lingual cingula surrounding the upper and lower molar valleys respectively, the increase of the number of roots on the second lower molar, and the lost of mesolophs on the upper molars. This suggests that $H$. bijugatus is a relatively derived with respect to the coeval congeneric species. 
For that reason a younger age is inferred for the localities La Grive L3 and L5, where this taxon has been recovered, than for La Grive $\mathrm{L} 7$ and $\mathrm{M}$ and for the unnamed fissurefilling, in which $H$. decedens has been found.

\section{Acknowledgements}

J. van Dam and W. Wessels (Rijksuniversiteit Utrecht, Utrecht) kindly lent material + of Hispanomys kept in their institution. Various aspects of this paper were improved thanks to the critical reading of J.-P. Aguilar (Université Montpellier 2, Montpellier) and M. A. Álvarez-Sierra (Universidad Complutense, Madrid), L. Celià Gelabert and J.

Galindo Torres (Instituto Catalán de Paleontología, Sabadell) allowed the examination of material under their care. This study has been partly founded by research project CGL2008-05813-CO2-01 conducted by J. Morales. R.L.A. holds a Ramón y Cajal contract.

\section{References}

Adrover, R., 1986. Nuevas faunas de roedores en el Mio-Plioceno continental de la región de Teruel (España). Interés bioestratigráfico y paleoecológico. Teruel: Instituto de estudios Turolenses.

Aguilar, J.P., 1982. Contributions à l'étude des Micromammifères du gisement Miocène supérieur de Montredon (Hérault) 2- Les rongeurs. Palaeovertebrata 12, 75-140.

Aguilar, J.P., Agusti, J., Gibert, J., 1979. Rongeurs miocènes dans le Vallès- Penedès. 2- Les rongeurs de Castell de Barbera. Palaeovertebrata 9, 17-31.
Formatted: Left, Don't adjust space between Latin and Asian text, Don't adjust space between Asian text and numbers

Formatted: Font: (Default) Times New Roman, 12 pt, English (U.K.)

Formatted: Font: Not Bold

Formatted: Font: Not Bold

Formatted: Font: Not Bold

Formatted: Font: Not Bold

Formatted: Font: Not Bold 
Aguilar, J.P., Calvet, M., Michaux, J., 1994. Les rongeurs de Castelnou 6 (Pyrénées Orientales, France) et les corrélations entre faunes ibériques et françaises au Miocène moyen. Neues Jahrbuch für Geologie und Paläontologie, Abhandlungen 192, 109-131. Aguilar, J.P., Escarguel, G., Michaux, J., 1999. A succession of Miocene rodent assemblages from fissure fillings in southern France, palaeoenvironmental interpretation and comparison with Spain. Palaeogeography, Palaeoclimatology, Palaeoecology 145, 215-230.

Aguilar, J.P., Michaux, J., Lazzari, V., 2007. Lo Fournas 16-M (Miocène supérieur) et Lo Fournas 16-P (Pliocène moyen), deux nouvelles localités karstiques à Baixas, Sud de la France. Géologie de la France 1, 63-81.

Agustí, J., 1977a. Contribución al conocimiento del género Hispanomys (Cricetidae, Rodentia, Mammalia) en la cuenca miocénica del Vallès-Penedès. Boletin Informativo Instituto de Paleontologia de Sabadell 9, 30-32.

Agustí, J., 1977b. Descripción de Cricetodon lavocati Freudenthal, 1966, de Sant Quirze (Trinxera). Paleontología y Evolución 12,65-67.

Agustí, J., 1978. El Vallesiense inferior de la Península Ibérica y su fauna de roedores (Mammalia). Acta Geológica Hispánica 13, 137-141.

Agustí, J., 1980. La asociación de Hispanomys y Cricetodon (Rodentia, Mammalia) en el Mioceno Superior del Vallès-Penedès (Cataluña, España). Acta Geológica Hispánica 15, 51-60.

Agustí, J., 1981. Roedores miomorfos del Neógeno de Cataluña. Ph.D. dissertation. Universidad de Barcelona, Barcelona.

Agustí, J., 1982. Tendencias evolutivas de la línea Cricetodon-Ruscinomys (Rodentia, Mammalia) en la Península Ibérica. Acta Geologica Hispánica 17, 103-111. 
Agustí, J., 1984. Contribución al conocimiento de los Cricétidos (Rodentia, Mammalia) de Can Llobateres (Mioceno superior del Vallès, España). In: anonymous (Ed.), Volume d'hommage au géologue Georges Zbyszewski. Éditions Recherche sur les Civilisations, Paris, pp. 257-267.

Agustí, J., 1986. Nouvelles espèces de cricetides vicariantes dans le Turolien moyen de Fortuna (Prov. Murcia, Espagne). Geobios 19, 5-11.

Agustí, J., Gibert, J., 1979. Nuevos datos sobre los roedores e insectívoros (Mammalia) del Mioceno superior del Vallès (Cataluña, España). Paleontologia i Evolució 14, 17-20.

Agustí, J., Gibert, J., 1982. Roedores e insectívoros (Mammalia) del Mioceno Superior de Can Jofresa y Can Perellada (Vallès-Penedès, Cataluña). Paleontologia i Evolució 17, 29-41.

Agustí, J., Cabrera, L., Garcés, M., Parés Josep, M., 1997. The Vallesian mammal succession in the Vallés-Penedés basin (northeast Spain): paleomagnetic calibration and correlation with global events. Palaeogeography, Palaeoclimatology, Palaeoecology 133, 149-180.

Agustí, J., Garcés, M., Krijgsman, W., 1999. Investigaciones bioestratigráficas y magnetoestratigráficas en la Cuenca de Fortuna (Murcia) y sus implicaciones para la evolución de la cuenca mediterránea durante el Messiniense (Mioceno superior). Memorias de Arqueología 14, 27-36.

Agustí, J., Casanovas-Vilar, I., Furió, M., 2005. Rodents, insectivores and chiropterans (Mammalia) from the late Aragonian of Can Missert (Middle Miocene, VallèsPenedès Basin, Spain). Geobios 38, 575-583. 
Agustí, J., Garcés, M., Krijgsman, W., 2006. Evidence for African-Iberian exchanges during the Messinian in the Spanish mammalian record. Palaeogeography, Palaeoclimatology, Palaeoecology 238, 5-14.

Alba, D.M., Moyà-Solà, S., Casanovas-Vilar, I., Galindo, J., Robles, J.M., Rotgers, C., Furió, M., Angelone, C., Köhler, M., Garcés, M., Cabrera, L., Almécija, S., Obradó, P., 2006. Los vertebrados fósiles del Abocador de Can Mata (els Hostalets de Pierola, l’Anoia, Cataluña). Estudios Geológicos 62, 295-312.

Alcalá, L., Sesé, C., Herráez, E., Adrover, R., 1991. Mamiferos del Turoliense inferior de Puente Minero (Teruel, España). Boletín de la Real Sociedad Española de Historia Natural Sección Geológica 86, 205-251.

Alcalá, L., Van Dam, J., Luque, L., Montoya, P., Abella, J., 2005. Nuevos mamíferos vallesienses en Masía de La Roma (Cuenca de Teruel). Geogaceta 37, 199-202.

Antunes, M., 1984. Essai de synthèse sur les Mammifères du Miocène du Portugal. In anonymous (Ed.), Volume d'hommage au géologue Georges Zbyszewski. Éditions Recherche sur les Civilisations, Paris, pp. 301-323.

Antunes, M., Mein, P., 1979. Le gisement de Freiria de Rio Maior, Portugal, et sa faune de mammifères; nouvelle espèce de Rotundomys, conséquences stratigraphiques. Geobios 12, 913-919.

De Bruijn, H., Mein, P., Montenat, C., Van De Weerd, A., 1975. Corrélations entre les gisements de rongeurs et les formations marines du Miocène terminal d'Espagne Méridional. I (Provinces d'Alicante et de Murcia). Proceedings of the Koninklijke Nederlandse Akademie van Wetenschappen B 78, 282-313. 
Calvo, J.P., Elizaga, E., López Martínez, N., Robles, F., Usera, J., 1978. El Mioceno superior continental del Prebético Externo: Evolución del Estrecho Nordbético. Boletín Geológico y Minero 89, 407-426.

Casanovas Vilar, I., 2007. The rodent assemblages from the Late Aragonian and the Vallesian (Middle to Late Miocene) of the Vallès-Penedès basin (Catalonia, Spain). Ph.D. dissertation. Universidad de Barcelona, Barcelona.

Casanovas-Vilar, I., Furió, M., Agustí, J., 2006. Rodents, insectivores and paleoenvironment associated to the first-appearing Hipparionine horses in the Vallès-Penedès Basin (Northeastern Spain). Beiträge zur Paläontologie 30, 1-19.

Crusafont M, Casanovas L. 1973. Mammalia Tertiaria Hispaniae. Fossilium Catalogus, I: Animalia, pars. 121, The Hague: Pasmans.

Engesser, B., 1972. Die obermiozäne Säugetierfauna von Anwil (Baselland).

Tätigkeitsbericht Naturforschende Gesellschaft Baselland 28, 37-363.

Freudenthal, M., 1966. On the mammalian fauna of the Hipparion beds in the Calatayud-Teruel basin (province of Zaragoza, Spain) Part I: The genera Cricetodon and Ruscinomys (Rodentia). Proceedings of the Koninklijke Nederlandse Akademie Van Wetenschappen B 69, 296-317.

Freudenthal, M., Lacomba, J.I., Martín-Suárez, E., 1991. The Cricetidae (Mammalia, Rodentia) from the Late Miocene of Crevillente (prov. Alicante, Spain). Scripta Geologica 96, 9-46.

Freudenthal, M., Hugueney, M., Moissenet, E., 1994. The genus Pseudocricetodon

(Cricetidae, Mammalia) in the Upper Oligocene of the province of Teruel (Spain). Scripta Geologica 104, 57-114. 
García-Alix, A., Minwer-Barakat, R., Martín-Suárez, E., Freudenthal, M., 2008.

Cricetidae and Gliridae (Rodentia, Mammalia) from the Miocene and Pliocene of southern Spain. Scripta Geologica 136, 1-37.

Gibert, J., Agustí, J., Moyà-Solà, S., 1980. Nuevos datos sobre la bioestratigrafía del Ampurdan. Boletín Geológico y Minero 91, 705-712.

Guérin, C., Mein, P., 1971. Les principaux gisements de mammifères miocènes et pliocènes $\mathrm{du}$ domaine rhodanien. In $\mathrm{V}^{\mathrm{e}}$ Congrès du Néogène méditerranéen. Documents des Laboratoires de Géologie de Lyon 1, 131-170.

Hartenberger, J.L., 1965. Les Cricetidae (Rodentia) de Can Llobateres (Néogène d'Espagne). Bulletin de la Société Géologique de France 7, 487-498.

Hartenberger, J.L., Thaler, L., 1963. Sur les Rongeurs fossiles du Vallésien de Can Llobateres (Sabadell, Espagne). Comptes rendus de 1'Académie des Sciences 256, $3333-3336$.

International Commission On Zoological Nomenclature. 1999. International Code of Zoological Nomenclature. London: The Natural History Museum.

Lacomba Andueza, J.I., 1988. Rodents and lagomorphs from a lower Vallesian fissure filling near Molina de Aragon (prov. Guadalajara, Spain). Scripta Geologica Special Issue 1, 19-38.

López Martínez, N., Sesé Benito, C., Sanz García, J.L., 1977. La microfauna (Rodentia, Insecta, Lagomorpha y Reptilia) de las fissuras del Mioceno medio de Escobosa de Calatañazor (Soria, España). Acta Geologica Hispanica 12, 47-73.

López Guerrero, P., Alvárez-Sierra, M.A., López-Antoñanzas, R., Oliver Pérez, A., Peláez-Campomanes, P. 2008. Cricetodontini (Cricetidae, Rodentia) del 
Aragoniense superior (Mioceno medio) de Nombrevilla 2, (Zaragoza, España).

Publicaciones del Seminario de Paleontología de Zaragoza 8, 259-271.

Maridet, O., 2003. Révision du genre Democricetodon (Mammalia, Rodentia,

Cricetinae) et dynamique des faunes de rongeurs du Néogène d'Europe

occidentale : évolution, paléobiodiversité et paléobiogéographie. Ph.D.

dissertation. Université Claude Bernard- Lyon 1, Lyon.

Mein, P., 1999. The late Miocene small mammal succession from France, with emphasis on the Rhone Valley localities. In Agustí J, Rook L, Andrews P (Eds.),

The Evolution of Neogene Terrestrial Ecosystems in Europe. Cambridge University Press, Cambridge, pp. 140-164.

Mein, P., Freudenthal, M., 1971. Une nouvelle classification des Cricetidae (Mammalia, Rodentia) du Tertiaire de l'Europe. Scripta Geologica 2, 1-37.

Mein, P., Ginsburg, L., 2002. Sur l'âge relatif des différents dépôts karstiques miocènes de La Grive-Saint-Alban (Isère). Cahiers scientifiques-Muséum d'Histoire naturelle de Lyon 2, 7-47.

Montuire, S., Maridet, O., Legendre, S. 2006. Late Miocene-Early Pliocene temperature $\underline{\text { estimates in Europe using rodents. Palaeogeography, Palaeoclimatology, }}$ Palaeoecology 238, 247-262.

Schaub, S., 1925. Die Hamsterartigen Nagetiere des Tertiärs und ihre lebenden 
Schaub, S., 1944. Cricetodontiden der Spanischen Halbinsel. Eclogae Geologicae Helvetiae 37, 453-457.

Schaub, S., 1947. Los Cricetodóntidos del Vallés-Panadés. Estudios Geologicos 6, 55 67.

Thaler, L., 1966. Les rongeurs fossiles du Bas Languedoc. Mémoires du Muséum National d'Histoire Naturelle, série C 17, 1-295.

Van Dam, J., Sanz Rubio, E., 2003. Late Miocene and Pliocene small mammals from the Calatayud Basin (Central Spain). Coloquios de Paleontología Vol. Ext. 1, 115126.

Van Dam, J., Alcala, L., Alonso Zarza, A., Calvo, J.P., Garces, G., Krijgsman, W., 2001. The Upper Miocene Mammal record from the Teruel-Alfambra region (Spain): The MN system and continental stage/age concepts discussed. Journal of Vertebrate Paleontology 21, 367-385.

Van de Weerd, A., 1976. Rodents fauna of the Mio-Pliocene continental sediments of the Teruel-Alfambra region, Spain. Utrecht micropaleontological bulletins, Special publication 2, 1-185. 


\section{FIGURE LEGENDS}

Fig. 1. Situation of the Saint-Alban-de-Roche municipality in France and close-up showing the situation of the different fossiliferous pits within it: CD24 "Chemin départemental 24”, L “carrière Lechartier”, M “carrière Milliat”, P. B. “carrière Peyre et Beau", and F "carrière nouvelle".

Fig. 2. Length/width scatter diagrams of the upper and lower molars of Hispanomys bijugatus from La Grive-Saint Alban (Carrière Lechartier, fissure L3).

Fig. 3. Lower molars of Hispanomys bijugatus. 1. Left m1 (FSL 66256). 2. Left m1 (FSL 66257). 3. Left m1 (FSL 66258). 4. Left m1 (FSL 66259). 5. Left m1 (FSL 66260). 6. Left m2 (FSL 66261). 7. Right m2 (FSL 66262). 8. Left m2 (FSL 66263). 9. Right m2 (FSL 66264). 10. Left m3 (FSL 66265). 11. Left m3 (FSL 66266). 12. Left m3 (FSL 66267). Scale bar represents $1 \mathrm{~mm}$.

Fig. 4. Upper molars of Hispanomys bijugatus. 1. Right maxilla fragment with M1M2 (FSL 66268). 2. Right M1 (FSL 66269). 3. Right maxilla fragment with M1-M2 (FSL 66270) and close-up showing the entomesoloph. 4. Close-up of the entomesoloph of specimen FSL 66270. 5. Left M1 (FSL 66271). 6. Right M1 (FSL 66272). 7. Right M2 (FSL 66273). 8. Left M2 (FSL 66274). 9. Right M2 (FSL 66275). 10. Left M2 (FSL 66276). 11. Right M3 (FSL 66277). 12. Right M3 (FSL 66278). 13. Right M3 (FSL 66279). 14. Right M3 (FSL 66280). Scale bar represents $1 \mathrm{~mm}$. 


\section{Figure 1}

Click here to download high resolution image
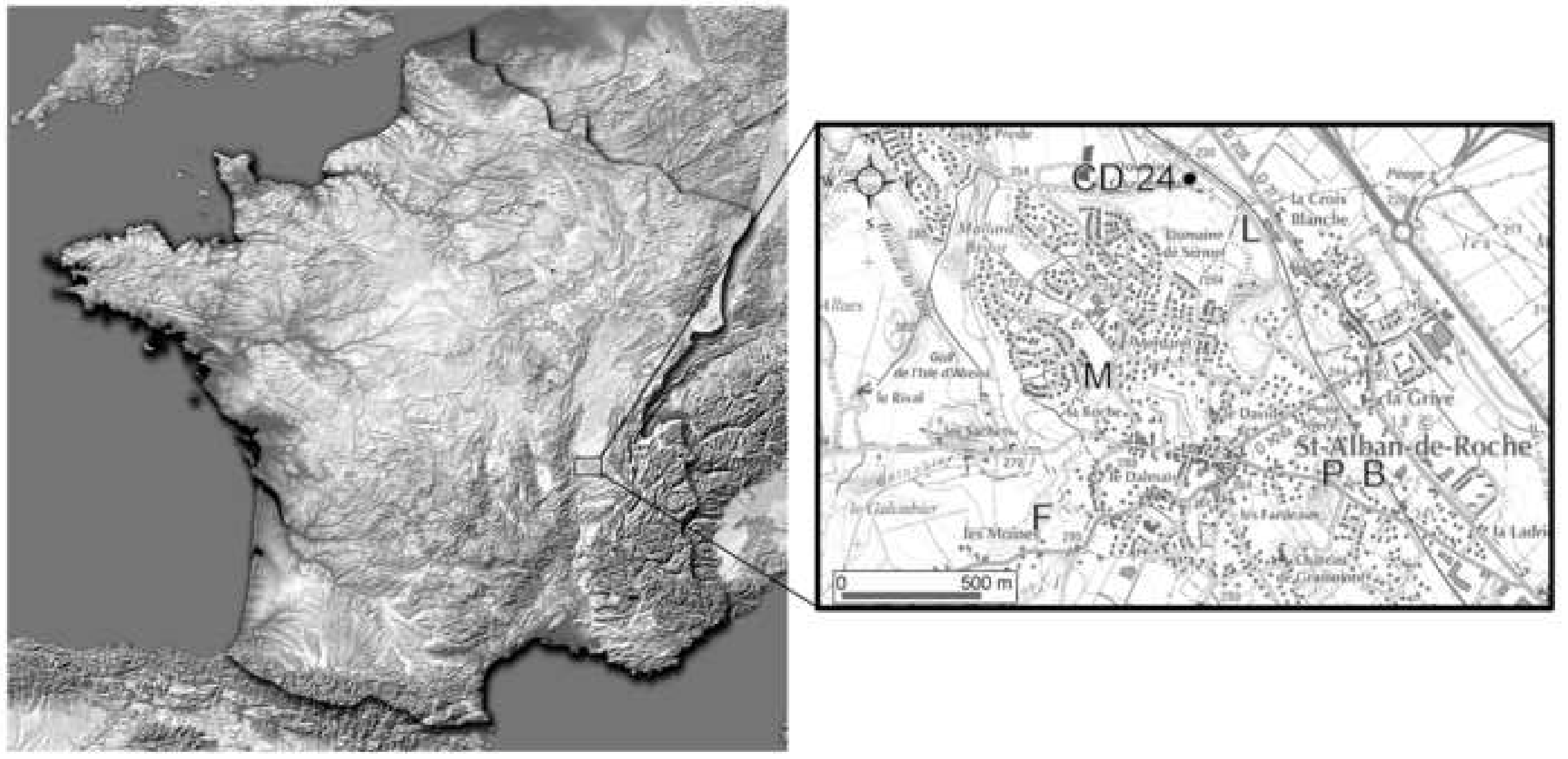
Click here to download high resolution image

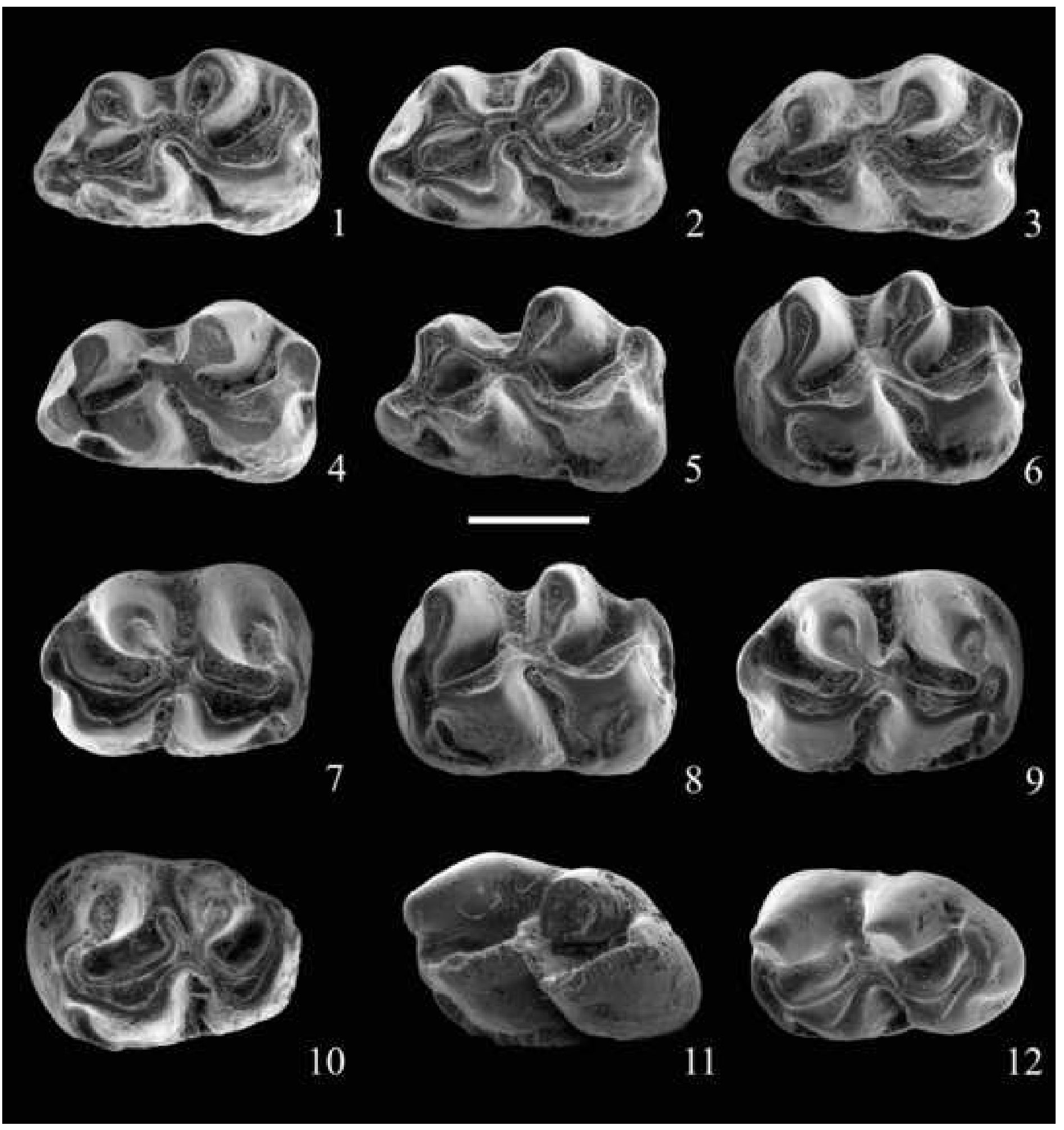


Click here to download high resolution image
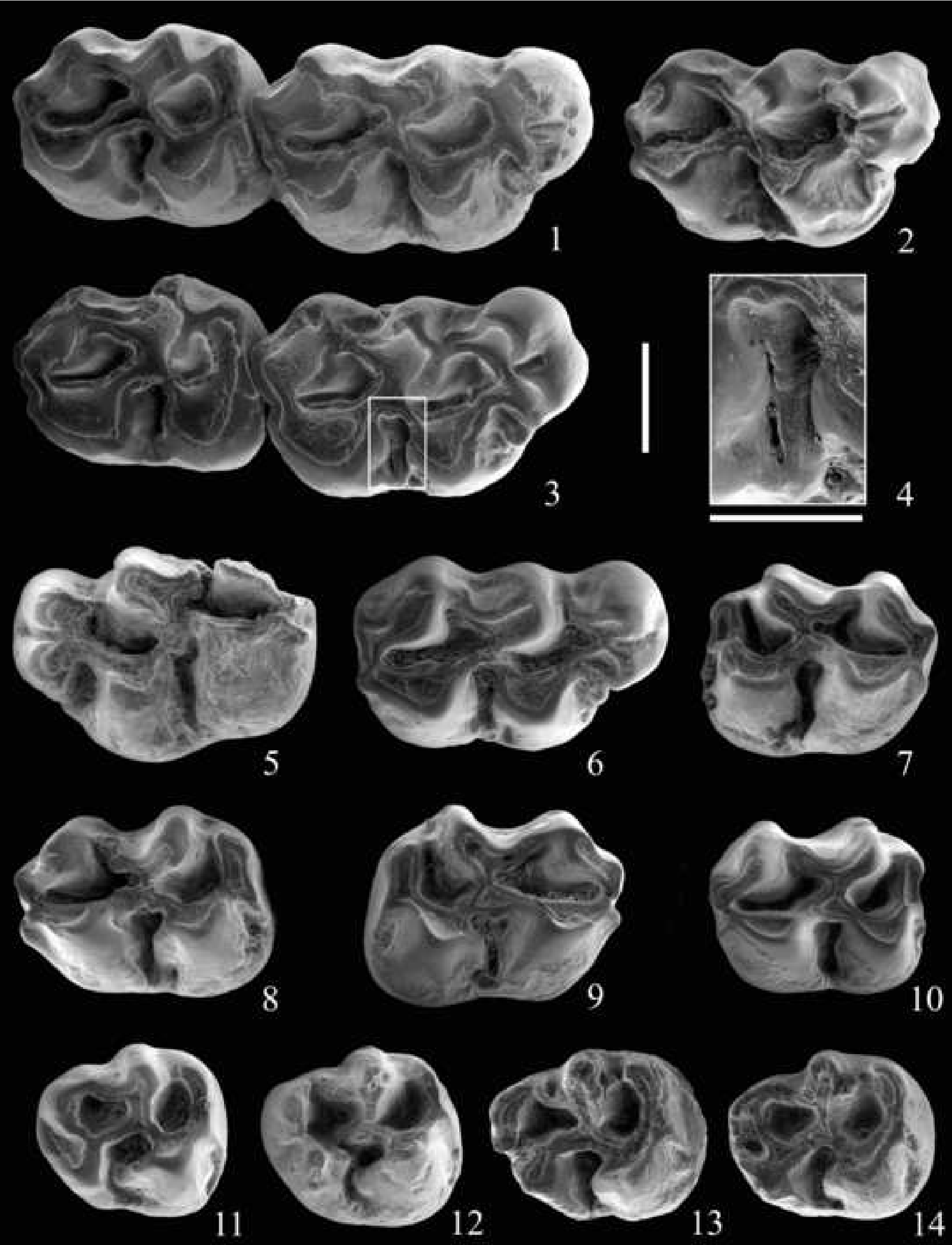


\section{TABLES}

Table 1. Length and width measurements $(\mathrm{mm})$ of the lower and upper molars of

Hispanomys bijugatus from La Grive-Saint Alban (Carrière Lechartier, fissure L3),

Isère, France.

\begin{tabular}{ccccccccccc}
\hline & \multicolumn{1}{c}{ LENGTH } & \multicolumn{7}{c}{ WIDTH } \\
\hline Locality & $\begin{array}{c}\text { Tooth } \\
\text { type }\end{array}$ & min & mean & max & sd & N & min & mean & max & sd \\
\hline La Grive-St Alban L3 & $\mathrm{m} 1$ & 2,44 & 2,60 & 2,80 & 0.09 & 50 & 1,54 & 1,63 & 1,81 & 0.07 \\
\hline La Grive-St Alban L3 & M1 & 2,97 & 3,23 & 3,50 & 0.11 & 49 & 1,92 & 2,05 & 2,18 & 0.06 \\
\hline La Grive-St Alban L3 & $\mathrm{m} 2$ & 2,40 & 2,54 & 2,74 & 0.08 & 43 & 1,65 & 1,83 & 1,93 & 0.06 \\
\hline La Grive-St Alban L3 & $\mathrm{M} 2$ & 2,30 & 2,47 & 2,61 & 0.08 & 42 & 1,80 & 1,92 & 2,07 & 0.07 \\
\hline La Grive-St Alban L3 & $\mathrm{m} 3$ & 2,32 & 2,47 & 2,72 & 0.07 & 39 & 1,58 & 1,68 & 1,80 & 0.06 \\
\hline La Grive-St Alban L3 & $\mathrm{M} 3$ & 1,80 & 1,97 & 2,18 & 0.08 & 41 & 1,57 & 1,70 & 1,93 & 0.07 \\
\hline
\end{tabular}


Table 2. M1/M3 (mm) length ratio for all species of Hispanomys known to date from various localities. Calculated from data in Aguilar (1982), Aguilar et al. (1994, 2007), Agustí (1977, 1980, 1981, 1986), Agustí et al. (2005), Casanovas-Vilar (2007), Casanovas-Vilar et al. (2006), Freudenthal et al. (1991), Lacomba (1988), López Martínez et al. (1977), Mein and Freudenthal (1971), van Dam (personal data, 2007), and van de Weerd (1976).

\begin{tabular}{|c|c|c|c|c|}
\hline Taxa & Locality & Age & Lm1/Lm3 & LM1/M3 \\
\hline H. adroveri & Casa del Acero & MN12 & 1.26 & 2.01 \\
\hline H. adroveri & Crevillente 15 & MN12 & 1.23 & 1.96 \\
\hline H. freudenthali & Masada del Valle 2 & MN12 & 1.23 & 1.90 \\
\hline H. freudenthali & Vivero de Pinos & MN11 & 1.19 & 2.06 \\
\hline H. freudenthali & Aguanaces & MN10/MN11 & 1.18 & 2.05 \\
\hline H. baixasi & Lo Fournas 16-M & MN11 & 1.13 & 1.85 \\
\hline H. baixasi & Lo Fournas 6 & MN11 & 1.13 & 1.77 \\
\hline H.peralensis & Crevillente 2 & MN11 & 1.17 & 1.83 \\
\hline H. peralensis & Peralejos C & MN10 J3 & 1.22 & 1.79 \\
\hline H. peralensis & Masía del Barbo 2B & MN10 J2 & 1.06 & 1.93 \\
\hline H. peralensis & Masía del Barbo 2A & MN10 J1 & 1.11 & 1.90 \\
\hline H.mediterraneus & Montredon & MN10 & 1.16 & 1.92 \\
\hline H. thaleri & Can Llobateres & MN9b & 1.24 & 1.86 \\
\hline H. thaleri & Riu Ripoll & MN9b & 1.11 & 1.82 \\
\hline H. thaleri & Can Ponsic & MN9b & 1.17 & 1.80 \\
\hline H. aragonensis & Pedregueras & MN9b & 1.16 & 1.78 \\
\hline H. nombrevillae & Molina de Aragón & MN9a & 1.25 & 1.86 \\
\hline H. nombrevillae & Nombrevilla & MN9a & 1.29 & 2.03 \\
\hline H. dispectus & Creu Conill 22 & MN9a & 1.16 & 1.79 \\
\hline H. dispectus & Creu Conill 20 & MN9a & 1.13 & 1.80 \\
\hline H. dispectus & Hostalets de Pierola (upper levels) & MN9a & 1.20 & 1.89 \\
\hline H. dispectus & Castell de Barbera & MN8 & 1.15 & 1.70 \\
\hline H. dispectus & Hostalets de Pierola (lower levels) & MN8 & 1.22 & 1.91 \\
\hline H. daamsi & Can Missert & MN8 & 1.08 & 1.78 \\
\hline H. lavocati & Saint Quirze & MN8 & 1.13 & 1.74 \\
\hline H. aguirrei & Escobosa & MN7/MN8 & 1.21 & 1.76 \\
\hline H. bijugatus & La Grive-Saint Alban & MN7/MN8 & 1.04 & 1.62 \\
\hline H. decedens & La Grive-Saint Alban & MN7/MN8 & 1.13 & 1.73 \\
\hline H. castelnovi & Castelnou 6 & MN6? & 1.17 & 1.83 \\
\hline
\end{tabular}




\section{* Detailed Response to Reviewers}

Madrid, le 30 mars 2009

Cher Collègue,

Veuillez trouver téléchargée la version corrigée de notre manuscrit intitulé «First detailed description of Hispanomys bijugatus Mein et Freudenthal, 1971 (Rodentia, Cricetodontinae) from the Upper Aragonian of La Grive-Saint Alban (France): biostratigraphical implications».

Les modifications sont indiquées grâce à l'outils «suivi des modification » de MS WORD. Nous avons pris en compte l'ensemble des suggestions des deux réviseurs, ce qui a amélioré notre étude.

Nous espérons que vous trouverez ce travail prêt à être publié dans Geobios et restons à votre disposition pour toute information supplémentaire.

Bien cordialement,

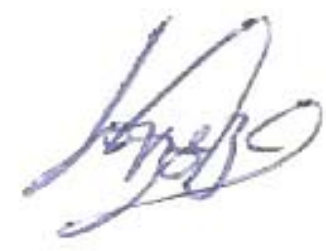

Raquel López-Antoñanzas 